\title{
THE GOVERNMENT POLICY IMPACT ON ECONOMIC DEVELOPMENT OF TOURISM
}

\author{
Aleksandra Vujko', Tamara Gajić2
}

\begin{abstract}
Summary
Tycoons and politicians are the main players of tourism in most parts of the world, and they often use tourism as a tool for gaining economic and political power, and creating a positive, albeit propagandized, image of their country. The paper is based on a positive example of an approved project by the Government of Vojvodina Secretariat for Science and Technological Development. The main goal of this paper is to show whether the local residents are familiar with the project and how much they know about project, and what is their opinion about the impact which this project or other similar projects have on the observed area (Fruška Gora Mountain-Serbia). The conclusion is that there is a direct positive relationship between residents' perceptions of the benefits of tourism and their political support. The method survey was conducted on a random sample of the residents of seven local settlements (the sample of 249 participants). The data were processed with the SPSS program (version 17.0). Chi-square test is used to determine the frequency of specific deviations.
\end{abstract}

Key words: tourism, government policy, economic development, local residents, Vojvodina.

JEL: Q56, Q58, R11, 013

\section{Introduction}

The Republic of Serbia is at a historic crossroads where intensive adaptation to European integration is conducted and where there is a strong growth in the competitive capacity of institutions, companies and individuals. Vojvodina is part of the Republic of Serbia which is currently defining development goals and economic sectors with prospect of success. Vojvodina will have to build and implement, both independently and with the support of the international community, competitive strategies of growth, as soon as possible. In this context, tourism is seen as an essential complex with increasing untapped potential.

1 Aleksandra Vujko, Ph.D., Lecturer, Novi Sad Business School, Vladimira Perića Valtera Street no. 4, 21000 Novi Sad, Serbia, Phone: +381 6491426 45, E-mail: aleksandravujko@yahoo.com

2 Tamara Gajić, Ph.D., Professor of professional studies, Novi Sad Business School, Vladimira Perića Valtera Street no. 4, 21000 Novi Sad, Serbia, Phone: +381 63565 544, E-mail: gajic_tamara@yahoo.com

EP 2014 (61) 3 (789-804) 
Fruška Gora Mountain (Vujko, 2011), as the potential, is not sufficiently valued, because tourism has not been a serious issue in the development policy of the Government of Vojvodina. Now there has been recognized comparative advantage in tourism of the mountain, because it has a variety of tourism supply, it is close to the traditional and emerging tourism markets, and it has a long history and a general recognition, preserved natural resources, a good proportion of communication and a great human potential. However, the process of transformation of comparative into competitive advantages in tourism of Fruška Gora Mountain is part of the reform process, and political relationship to tourism as an important creator of national prosperity.

The subject of the matter is it to show how well residents of Fruška Gora Mountain are familiar with the projects (opinions and attitudes of local residents from the area of the mountain), that will provide the maximum benefit for all involved "stakeholders", and minimizing the negative impacts of the processes and activities to create a highly valuable experience for tourists. The case study of this paper is the project: "Functional connection between the excursion tourism and cycling tourism in the Fruška Gora Mountain" initiated by the Provincial Secretariat for Science and Technological Development.

It is necessary to explore the awareness of local residents with active measures implemented by the Government of Vojvodina in order to reduce unemployment, their familiarity with the current project, and attitudes about the importance of the project for the development of the area. The research results should contribute to understanding the importance of tourism policy as a factor in securing the success of tourist destinations. Primarily, such tourism policy must provide a clear picture of future prospects for a destination like Fruška Gora Mountain, especially in the long term.

Tourism is attributed to the "power" to foster socio-economic and demographic development. There are numerous examples of entire regions where tourism is the dominant or unifying activity. They involve comparative economic advantages in relation to the regions which do not develop tourism. It is therefore not surprising when we refer to tourism as a development catalyst (Nunkoo, Smith, 2013). These effects are present in our experiential heritage, so they are considered logical, almost axiomatic. They clearly explain why tourism is recognized as an "industry-initiative" of demographic and economic recovery, but not sufficient for generalization according to which any attempt to tourism development necessarily results in prosperity.

For the purposes of this research, the survey was used as a method, whereby 250 questionnaires were distributed and 249 of them were analysed. This analysis led to the confirmation of the given hypothesis and refutation of other hypotheses. The SPSS program, version 17.0, and T-square test were used. In addition to the research data, the authors used the available statistical and other secondary documentation.

It has come to the conclusion that there is a direct positive relationship between residents' perceptions of the benefits of tourism and their political support; local residents are aware of the active measures of the Government of Vojvodina for the economic development of tourism; local residents positively evaluated all active measures of the Government of Vojvodina 
in their efforts to reduce the unemployment of the population. Among the existing active measures of the Government of Vojvodina, the local residents give the highest grades to the opportunity of self-employment; local residents are not familiar with the project: "Functional connection between the excursion tourism and cycling tourism in the Fruška Gora Mountain"; and local residents positively evaluated the implementation of projects related to tourism on the mountain.

\section{Literature review}

Institutionalists argue that the economic performance of government institutions is one of the strongest determinants of citizens' trust (Mishler, Rose, 2001; 2005). Citizens trust their government to the extent that its institutions produced desired economic outcomes and meet their expectations in the economic domain (Luhiste, 2006). Government's inability to deal with economic challenges such as unemployment and poverty impinges on citizens' trust. Nunkoo et al. (2012) reported that residents' perceptions of the economic performance of tourism institutions positively influenced political trust. Such a relationship has been validated by several studies in political science (Mishler, Rose, 2001; 2005; Wang, 2005; Wong et al., 2011).

The projects supported by the government institutions sublimate and encourage beneficial effects of other determinants and create numerous comparative advantages. Tourism thus reinforces those elements without which it does not work (transportation and utility infrastructure, ancillary service industries, aestheticized physiognomy of the settlement, urbanization, etc.), and acts as a complex factor. However, there is no uniformity. The power of tourism as a factor of economic growth varies depending on local factors - traffic and geographical location, degree of urbanization, proximity and importance of generating markets, tourist sites and types of demographic phenomena and processes that were found in this area.

Government is the principal actor in the political process of tourism development (Bramwell, 2011) and has usually adopted a more interventionist approach in tourism development than in other sectors (Ruhanen, 2013). Government controls the industry through formal ministries, other institutions, legislations, and various programs and funding initiatives (Elliot, 1997), and intervenes in tourism for environmental, political, and economic reasons (Nyaupane, Timothy, 2010). According to Hall (2005), government has seven functions in tourism development: coordination, planning, legislation and regulation, entrepreneurship, stimulation, social tourism, and public interest protection roles. Traditionally, economic concerns were the principal reasons for governments to intervene in tourism.

The negative effects of tourism and local residents' reluctance to accept development have meant that governments' roles in the sector have extended beyond economic considerations to address the environmental and social consequences of development. The diffusion of the sustainable development concept in the 1980s has also led governments to assume greater roles and responsibilities in tourism planning (Ruhanen, 2013). Governments now usually attempt to secure a balance between economic priorities, the environment, and the local residents in order to gain political support for tourism development (Bramwell, 2011). Political 
economy suggests that a politically stable relationship between the state and the local residents is important to maintain political legitimacy and effective authority (Purcell, Nevins, 2005) and to ensure the state's ability to reflect the popular will (Bramwell, 2011).

Political legitimacy cannot be achieved without local residents' trust in government and their support for tourism development. Political motives for controlling tourism are very powerful, but they are subtle because governments never overtly release statements and information about their hidden political agendas (Kim et al., 2007). Political reasons include nationalism and identity, isolationist desires, marred foreign relations, and unbalanced power relations. From a political perspective, tourism is targeted by many developing countries as a way of demonstrating their independence and importance in the world. In a tourism context, political economy suggests that it is important for government to maintain legitimacy and influence on government processes by ensuring that the local residents support its policies (Wang, Bramwell, 2012). Residents' support for tourism is influenced by their perceptions of the benefits and costs of the sector (Jackson, Inbarakan, 2006).

Tourism development results in investment opportunities, better infrastructure, employment opportunities, more public development, and improvement in the local economy (Latkova, Vogt, 2012; Nunkoo, Ramkissoon, 2009; 2011; 2012). Tourism also provides opportunities for cultural exchanges (Besculides et al., 2002) and increases entertainment opportunities for local residents (Liu, Var, 1986; Andereck, Nyaupane, 2011; Latkova, Vogt, 2012). Several studies report a positive relationship between perceived benefits and support for tourism (Latkova, Vogt, 2012; Nunkoo, Gursoy, 2012; Nunkoo, Ramkissoon, 2011). Political economy suggests that a key role for the government is intervention to encourage the conditions for capital accumulation and economic expansion (Bevir, 2009). In the context of tourism, government often gives priority to economic growth over environmental and social concerns (Wang, Bramwell, 2012).

\section{Research methodology}

This study was conducted on Fruška Gora Mountain, located in Vojvodina, Serbia. This region is one of the fastest-growing areas of Serbia. A review of existing policy documents and published studies on Fruška Gora Mountain indicates that although tourism makes significant contributions to the local economy, the development of the sector also leads to a number of adverse consequences such as conflicts between tourism developers and residents, environmental destruction, marginalization of local residents, inadequate public consultation and opposition to tourism development. Planning authorities in Vojvodina recognize the need for community involvement in the sustainable development of the region and this has been expressed in a number of policy documents (e.g. Serbia tourism development strategy, 2005).

The research was a combination of quantitative methods (statistics and web analysis) and qualitative methods (interviews, discussion and written documents). Bibliographic speculative was used in the phase of defining the theoretical framework, and descriptive method for data processing and results interpretation. The first part of this research was the field research and data collection through direct examination that was conducted in the area of Fruška Gora Mountain. We examined the local population of seven places on the Fruška Gora Moun- 
tain: Petrovaradin, Sremski Karlovci, Čortanovci, Ledinci, Sremska Kamenica, Erdevik and Banstol. The survey was conducted between May and August 2012, and the questionnaire consisted of questions grouped into independent and dependent variables.

Independent variables are a group of questions that are related to gender, age structure and education. In the second part of the results processing, the analysis of the dependent variables was done. The variables reflect the opinion of the participants about their familiarity with the project "Functional connection between the excursion tourism and cycling tourism in the Fruška Gora Mountain", and attitudes about the importance of the project for the development of the area. The participants were asked a set of questions in order to determine their familiarity with the active measures of the Government of Vojvodina to implement positive policies for tourism development. Also, the participants were asked to name the point, to describe as precisely as possible and to give their opinion on them.

The second part of the paper includes a "desk" research. The methodology involved the reading of official government documents available to the public. In fact, the subject of interest includes the incentives provided by the Government of Vojvodina for the economic development of tourism. They investigated all available sites and all supporting documentation of competent state institutions, such as Provincial Secretariat for Science and Technological Development of Vojvodina, Development Fund of the Republic of Serbia and the National Employment Service.

The study was started from the main hypothesis $\mathrm{H}$ : There is a direct positive relationship between residents' perceptions of the benefits of tourism and their political support. Under this hypothesis certain lower-level hypotheses are set: h1 - local residents are aware of the active measures of the Government of Vojvodina for the economic development of tourism; h2 - local residents positively evaluated all active measures of the Government of Vojvodina in their efforts to reduce the unemployment of the population. Among the existing active measures of the Government of Vojvodina, the local residents give the highest grades to the opportunity of self-employment; h3 - local residents are familiar with the project: "Functional connection between the excursion tourism and cycling tourism in the Fruška Gora Mountain"; h4 - local residents positively evaluated the implementation of projects related to tourism on the mountain.

\section{Results and discussion}

Out of the 250 questionnaires, 249 were analyzed, which makes fairly representative sample. In the survey, the participants were residents of the mountain in the following structure: Petrovaradin (41.8\%), Sremski Karlovci (12.4\%), Ledinci (12\%), Čortanovci (10.4\%), Banstol (6.8\%) and Erdevik (6.8\%). Regarding the age structure of the tourists, there are $61.4 \%$ of the male population and $38.6 \%$ of women. The largest percentage of them $(51 \%)$ is aged between 31 and 50, followed by $42.2 \%$ of those who are over 51 , then there are those aged from 16 to $30(2.1 \%)$, and the lowest number of participants is below $15(1.7 \%)$. The largest percentage of them $(78.5 \%)$ completed secondary school education, followed by $10.7 \%$ with university degree, $5.8 \%$ who completed college, $4.5 \%$ with elementary education, whereas $0.4 \%$ of them have M.Sc./Ph.D. degree. 
Table 1. Familiarity of local residents with the active measures of the Government of Vojvodina for the economic development of tourism

\begin{tabular}{|c|c|c|c|c|c|c|}
\hline \multicolumn{6}{|c|}{$\begin{array}{l}\text { Are you familiar with the Government of Vojvodina active } \\
\text { measures for the economic development of tourism? }\end{array}$} & \multirow{2}{*}{ In total } \\
\hline Gender & Education & \multicolumn{2}{|c|}{ Count $/ \%$} & Yes & No & \\
\hline \multirow{12}{*}{ Male } & \multirow{2}{*}{ Elementary education } & \multicolumn{2}{|c|}{ Count } & 5 & 3 & 8 \\
\hline & & \multicolumn{2}{|c|}{$\%$} & $3.4 \%$ & $2.1 \%$ & $5.5 \%$ \\
\hline & \multirow{2}{*}{$\begin{array}{l}\text { Secondary school } \\
\text { education }\end{array}$} & \multicolumn{2}{|c|}{ Count } & 121 & 0 & 121 \\
\hline & & \multicolumn{2}{|c|}{$\%$} & $82.9 \%$ & $0 \%$ & $82.9 \%$ \\
\hline & \multirow{2}{*}{ College } & \multicolumn{2}{|c|}{ Count } & 2 & 0 & 2 \\
\hline & & \multicolumn{2}{|c|}{$\%$} & $1.4 \%$ & $0 \%$ & $1.4 \%$ \\
\hline & \multirow{2}{*}{ University degree } & \multicolumn{2}{|c|}{ Count } & 14 & 0 & 14 \\
\hline & & \multicolumn{2}{|c|}{$\%$} & $9.6 \%$ & $0 \%$ & $9.6 \%$ \\
\hline & \multirow{2}{*}{ MSc/PhD } & \multicolumn{2}{|c|}{ Count } & 1 & 0 & 1 \\
\hline & & \multicolumn{2}{|c|}{$\%$} & $0.7 \%$ & $0 \%$ & $0.7 \%$ \\
\hline & \multirow{2}{*}{ Total } & \multicolumn{2}{|c|}{ Count } & 143 & 3 & 146 \\
\hline & & \multicolumn{2}{|c|}{$\%$} & $97.9 \%$ & $2.1 \%$ & $100.0 \%$ \\
\hline \multirow{10}{*}{ Female } & \multirow{2}{*}{ Elementary education } & \multicolumn{2}{|c|}{ Count } & 3 & 0 & 3 \\
\hline & & \multicolumn{2}{|c|}{$\%$ of Total } & $3.3 \%$ & 0 & $3.3 \%$ \\
\hline & \multirow{2}{*}{$\begin{array}{l}\text { Secondary school } \\
\text { education }\end{array}$} & \multicolumn{2}{|c|}{ Count } & 65 & 0 & 65 \\
\hline & & \multicolumn{2}{|c|}{$\%$ of Total } & $70.7 \%$ & 0 & $70.7 \%$ \\
\hline & \multirow{2}{*}{ College } & \multicolumn{2}{|c|}{ Count } & 12 & 0 & 12 \\
\hline & & \multicolumn{2}{|c|}{$\%$ of Total } & $13.0 \%$ & 0 & $13.0 \%$ \\
\hline & University deareo & \multicolumn{2}{|c|}{ Count } & 12 & 0 & 12 \\
\hline & University aegree & $\%$ & & $13.0 \%$ & 0 & $13.0 \%$ \\
\hline & & & & 92 & 0 & 92 \\
\hline & $\% 0$ & & & $100.0 \%$ & 0 & $100.0 \%$ \\
\hline & ttachment 1. & Value & df & Statisti & I significa & ce (p) \\
\hline Pearson Ch & Square & 53.836 & 4 & & 0.000 & \\
\hline
\end{tabular}

Source: research by authors

The results showed that almost all participants (Table 1) are familiar with the active measures of the Government of Vojvodina for the economic development of tourism. After examining the same table (Attachment 1) it can be concluded that there is a statistically significant difference in responses, which is $\mathrm{p}=0.000$. By analysing this data it can be concluded that the cause derives from the objective differences of participants. In fact, only three participants $(2.1 \%)$ responded negatively to the question, and they are representatives of a younger population (grammar school) so it is not so surprising. 
Table 2. The measures of the Government of Vojvodina

\begin{tabular}{|c|r|r|r|r|r|}
\hline \multicolumn{7}{|c|}{ What are the measures of the Government of Vojvodina? } \\
\hline \multirow{2}{*}{ Gender } & \multicolumn{1}{c|}{ Projects } & \multicolumn{1}{c|}{ Loans } & Subsidies & Do not know & In total \\
\hline \multirow{2}{*}{ Male } & 43 & 51 & 56 & 3 & 153 \\
\cline { 2 - 6 } & $17.3 \%$ & $20.5 \%$ & $22.5 \%$ & $1.2 \%$ & $61.4 \%$ \\
\hline \multirow{2}{*}{ Female } & 25 & 57 & 14 & 0 & 96 \\
\hline \multirow{2}{*}{ In total } & $10.0 \%$ & $22.9 \%$ & $5.6 \%$ & $0 \%$ & $38.6 \%$ \\
\cline { 2 - 6 } & 68 & 108 & 70 & 3 & 249 \\
\cline { 2 - 6 } & $27.3 \%$ & $43.4 \%$ & $28.1 \%$ & $1.2 \%$ & $100.0 \%$ \\
\hline
\end{tabular}

Source: research by authors

The results that can be seen in Table 2 show the degree of familiarity of the local residents with the measures of the Government of Vojvodina. It was interesting that the $98.8 \%$ of the participants responded that these measures appear in the forms of loans, various projects and subsidies. The analysis of the data confirmed lower-level hypothesis 1 (h1) which states that the local residents are familiar with the active measures of the Government of Vojvodina for the economic development of tourism.

After examining the table 3 it can be concluded that the same percentage of the population $(98.8 \%)$ all the measures of the Government of Vojvodina are experiencing positive.

Table 3. The evaluated measures by the local residents

\begin{tabular}{|l|r|r|r|}
\hline \multicolumn{3}{|c|}{ How do you evaluate these measures of the Government of Vojvodina? } \\
\hline Gender & Positive & Do not know & \multicolumn{1}{|c|}{ In Total } \\
\hline \multirow{2}{*}{ Male } & 150 & 3 & 153 \\
\cline { 2 - 4 } & $60.2 \%$ & $1.2 \%$ & $61.4 \%$ \\
\hline \multirow{2}{*}{ Female } & 96 & 0 & 96 \\
\cline { 2 - 5 } & $38.6 \%$ & $0 \%$ & $38.6 \%$ \\
\hline \multirow{2}{*}{ In total } & 246 & 3 & 249 \\
\cline { 2 - 4 } & $98.8 \%$ & $1.2 \%$ & $100.0 \%$ \\
\hline
\end{tabular}

Source: research by authors

In Table 4 there are the participants' answers about the positive aspects of all measures of the Government of Vojvodina. The high percentage of the answers includes self-employment $(35.7 \%)$, and new jobs $(30.9 \%)$.

In fact, the participants positively evaluate all measures of the Government of Vojvodina, and the different responses can be seen in the responses of male and female participants.

The male participants give the highest score for self-employment $(25.5 \%)$, and the female participants give the highest score for new jobs (15.7\%). By the analysis of the data it can be seen that lower-level hypothesis $2(\mathrm{~h} 2)$ is confirmed that the local population is experiencing as positive all the active measures of the Government of Vojvodina in their efforts to reduce the unemployment rate. Based on the values $\mathrm{p}=0.010$ there can be seen statistically significant differences in responses of different categories (Attachment 1). 
Table 4. The positive aspects of measures of the Government of Vojvodina

\begin{tabular}{|c|c|c|c|c|c|c|}
\hline \multicolumn{7}{|c|}{ What are the positive aspects? } \\
\hline Gender & $\begin{array}{l}\text { New } \\
\text { jobs }\end{array}$ & $\begin{array}{c}\text { Self- } \\
\text { employment }\end{array}$ & $\begin{array}{c}\text { The revival of } \\
\text { the villages }\end{array}$ & $\begin{array}{c}\text { Area } \\
\text { development }\end{array}$ & Do not know & In total \\
\hline \multirow{2}{*}{ Male } & 38 & 66 & 27 & 19 & 3 & 153 \\
\hline & $15.3 \%$ & $26.5 \%$ & $10.8 \%$ & $7.6 \%$ & $1.2 \%$ & $61.4 \%$ \\
\hline \multirow{2}{*}{ Female } & 39 & 23 & 19 & 15 & 0 & 96 \\
\hline & $15.7 \%$ & $9.2 \%$ & $7.6 \%$ & $6.0 \%$ & $0 \%$ & $38.6 \%$ \\
\hline \multirow{2}{*}{ In total } & 77 & 89 & 46 & 34 & 3 & 249 \\
\hline & $30.9 \%$ & $35.7 \%$ & $18.5 \%$ & $13.7 \%$ & $1.2 \%$ & $100.0 \%$ \\
\hline \multicolumn{2}{|c|}{ Attachment 1.} & Value & \multicolumn{2}{|c|}{ df } & \multicolumn{2}{|c|}{\begin{tabular}{|l} 
Statistical significance (p) \\
\end{tabular}} \\
\hline \multicolumn{2}{|c|}{$\begin{array}{l}\text { Pearson Chi- } \\
\text { Square }\end{array}$} & 13.299 & \multicolumn{2}{|c|}{4} & \multicolumn{2}{|l|}{0.010} \\
\hline
\end{tabular}

Source: research by authors

Table 5. Familiarity with the project "Functional connection between the excursion tourism and cycling tourism in the Fruška Gora Mountain"

\begin{tabular}{|l|r|r|r|r|}
\hline Have you heard of the project "Functional connection between the excursion tourism and cycling \\
tourism in the Fruška Gora Mountain"?
\end{tabular}

Source: research by authors

The results seen in Table 5 and Table 6 show that the locals were not familiar with the project "Functional connection between the excursion tourism and cycling tourism in the Fruška Gora Mountain" (Table 5), but they show extremely positive remarks concerning its influence on the development of a destination. These data suggest that the lower-level hypothesis h3 is not correct (Table 5), but that lower-level hypothesis h4 is correct (Table 6). 
Table 6. Possible significance of the project "Functional connection between the excursion tourism and cycling tourism in the Fruška Gora Mountain"

\begin{tabular}{|c|c|c|c|c|c|c|c|}
\hline \multicolumn{8}{|c|}{ If the project has achieved what should reflect its significance? } \\
\hline Gender & 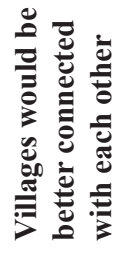 & 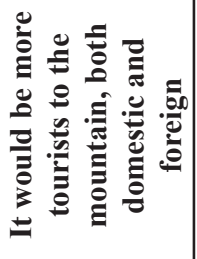 & 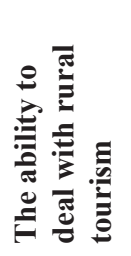 & 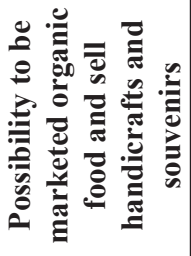 & 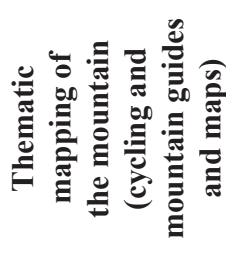 & 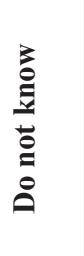 & $\begin{array}{l}\vec{\sigma} \\
\stackrel{\tilde{\theta}}{\Xi} \\
\Xi\end{array}$ \\
\hline \multirow{2}{*}{ Male } & 19 & 35 & 29 & 35 & 32 & 3 & 153 \\
\hline & $7.6 \%$ & $14.1 \%$ & $11.6 \%$ & $14.1 \%$ & $12.9 \%$ & $1.2 \%$ & $61.4 \%$ \\
\hline \multirow{2}{*}{ Female } & 17 & 20 & 28 & 20 & 11 & 0 & 96 \\
\hline & $6.8 \%$ & $8.0 \%$ & $11.2 \%$ & $8.0 \%$ & $4.4 \%$ & $0 \%$ & $38.6 \%$ \\
\hline \multirow{2}{*}{ In total } & 36 & 55 & 57 & 55 & 43 & 3 & 249 \\
\hline & $14.5 \%$ & $22.1 \%$ & $22.9 \%$ & $22.1 \%$ & $17.3 \%$ & $1.2 \%$ & $100.0 \%$ \\
\hline \multicolumn{2}{|c|}{ Attachment 2.} & \multicolumn{2}{|c|}{ Value } & \multicolumn{2}{|r|}{ df } & \multicolumn{2}{|c|}{ St. sign. (p) } \\
\hline \multicolumn{2}{|l|}{ Test } & \multicolumn{2}{|c|}{8.989} & \multicolumn{2}{|r|}{5} & \multicolumn{2}{|c|}{0.109} \\
\hline
\end{tabular}

Source: research by authors

The public competition for co-funding of the projects of importance for science and technological development of the AP Vojvodina for the period 2011-2014 was opened during February 2 - 28, 2011. The Provincial Secretariat for Science and Technological Development, in accordance with its financial capacities, in the past years (2005-2011) approved co-funding of 92 projects (Table 7).

Table 7. The number of co-funded projects in Vojvodina per areas (2005-2011)

\begin{tabular}{|c|c|c|c|c|c|c|c|}
\hline Scientific area & \multicolumn{8}{|c|}{ Number of projects } \\
\hline & $\mathbf{2 0 0 5}$ & $\mathbf{2 0 0 6}$ & $\mathbf{2 0 0 7}$ & $\mathbf{2 0 0 8}$ & $\mathbf{2 0 0 9}$ & $\mathbf{2 0 1 0}$ & $\mathbf{2 0 1 1}$ \\
\cline { 2 - 8 } & 10 & 13 & 14 & 15 & 14 & 14 & 12 \\
\cline { 2 - 8 } Social Sciences and Humanities & \multicolumn{8}{|c|}{ Allotted sum (\%)/RSD } \\
\cline { 2 - 8 } & $\mathbf{2 0 0 5}$ & $\mathbf{2 0 0 6}$ & $\mathbf{2 0 0 7}$ & $\mathbf{2 0 0 8}$ & $\mathbf{2 0 0 9}$ & $\mathbf{2 0 1 0}$ & $\mathbf{2 0 1 1}$ \\
\cline { 2 - 8 } & 11.7 & 11.6 & 14.86 & 13.92 & 14.12 & 14.79 & 13.37 \\
\hline
\end{tabular}

Source: The Provincial Secretariat for Science and Technological Development of Vojvodina

The results seen in Table 8 show in 2011 two municipalities in the area of Fruška Gora Mountains were granted funding. It certainly suggests that these municipalities also did some projects that contribute to the economic development of tourism.

Table 8. The loan funds by municipalities on the Fruška Gora Mountain (in 2011, in RSD)

\begin{tabular}{|l|r|r|r|}
\hline \multicolumn{1}{|c|}{ Municipalities } & Number of loans & The estimated value & \multicolumn{1}{c|}{ The approved loan } \\
\hline Irig & 1 & $742,000,000.00$ & $200,000,000.00$ \\
\hline Sremski Karlovci & 1 & $1,500,000.00$ & $1,195,976.00$ \\
\hline
\end{tabular}

Source: The Development Fund of the Republic of Serbia 
The results seen in Table 9 show the amount of funds earmarked for the development of project documentation for the project: "Functional connection between the excursion tourism and cycling tourism in the Fruška Gora Mountain".

Table 9. Approved funding for the project from the "Right at the first chance" (in RSD)

\begin{tabular}{|l|l|}
\hline $\begin{array}{l}\text { The project: "Functional connection between the excursion tourism and } \\
\text { cycling tourism in the Fruška Gora Mountain" }\end{array}$ & $1,414,702.96$ \\
\hline
\end{tabular}

Source: research by authors

Table 10. The Government subsidies and loans that were valid (2011)

\begin{tabular}{|c|c|}
\hline \multirow{7}{*}{$\begin{array}{l}\text { Programs of the National Employment } \\
\text { Service by } 2011 .\end{array}$} & $\begin{array}{l}\text { Public competition for the organization of the } \\
\text { implementation of public works. }\end{array}$ \\
\hline & $\begin{array}{l}\text { Public invitation for granting subsidies to employ- } \\
\text { ers to create new jobs. }\end{array}$ \\
\hline & $\begin{array}{l}\text { Public invitation for granting unemployed subsidies } \\
\text { for self-employment. }\end{array}$ \\
\hline & $\begin{array}{l}\text { Competition for the implementation of measures of } \\
\text { professional practice. }\end{array}$ \\
\hline & $\begin{array}{l}\text { Competition for the realization of the program } \\
\text { "First Chance, 2011." }\end{array}$ \\
\hline & $\begin{array}{l}\text { Competition for funding training programs for em- } \\
\text { ployers. }\end{array}$ \\
\hline & $\begin{array}{l}\text { Public call to local governments to engage in } \\
\text { the financing of programs and active labour market } \\
\text { measures. }\end{array}$ \\
\hline \multirow[t]{2}{*}{ Encouraging new employment } & $\begin{array}{l}\text { An employer may use the deduction provided to get } \\
\text { employed indefinitely with persons in the following } \\
\text { categories: people older than } 45 / 50 \text {, the trainees un- } \\
\text { der } 30 \text {; persons under } 30 \text { years of Persons with Dis- } \\
\text { abilities. }\end{array}$ \\
\hline & $\begin{array}{l}\text { Exemption from payment of contributions can } \\
\text { not realize state agencies and organizations, public } \\
\text { enterprises, public services and other direct and in- } \\
\text { direct budget users. }\end{array}$ \\
\hline Regional employment programs & $\begin{array}{l}\text { The subsidy is granted as a lump sum of } \\
100,000.00 \text { RSD per newly employed person. }\end{array}$ \\
\hline \multirow{6}{*}{ Development Fund of the Republic of Serbia } & Loans to companies \\
\hline & Loans for entrepreneurs \\
\hline & Loans to convert innovation into a finished product \\
\hline & Loans for unemployed \\
\hline & Loans for Beginners \\
\hline & $\begin{array}{l}\text { Loans and incentives for enterprise development in } \\
\text { the least developed municipalities }\end{array}$ \\
\hline
\end{tabular}

Source: The National Employment Service 
The impact of tourism on the changes in the economic structure of the population is based on the labour-intensive nature of this activity since it was accompanied by increasing tourism activities. The specific scope of the manpower in tourism, at first glance, is the most reliable indicator of the economic importance of tourism.

Although the number of active employees in a particular activity does not have to be confirmation of its importance in the total domestic product, when it comes to tourism as a labour-intensive activity, the volume of active employees indicates the development trends of tourism.

Tourism is very important in developed regions, and it is not only one of the activities because it creates numerous jobs directly and indirectly. Bearing in mind that Serbia is one of those countries which are just beginning to form a new regional tourism destination in its economic policy, there are two main ways for the development of tourism: the formal principle of regulating tourism through legal measures and regulations that enable tourism development; or directly, through the material principle, i.e. the allocation of funds for specific development programs.

Those are specific subsidies and financial incentives for promising projects, which are part of the budgetary cost, so they are usually non-refundable. On the other hand, this results in channelling investment funds through selective credit and monetary policy, with flexible repayment terms and interest rates (Table 10). This way of economic policy led to the Government of Vojvodina to efficiently build all capacities with the shortest period of return on investment. All given tables (from 1 to 10 ) provide data that confirm the main hypothesis: that there is a direct positive relationship between residents' perceptions of the benefits of tourism and their political support.

\section{Conclusion}

For the purposes of the research, the authors conducted survey in the area of Fruška Gora Mountain. The starting points were assumptions, or more precisely, certain hypotheses and sub-hypotheses that should be proved or disproved. The conclusion is that there is a direct positive relationship between residents' perceptions of the benefits of tourism and their political support. In addition to these findings, the authors have used statistical and other information, as well as other available documentation. Based on the analysis of survey data it is confirmed that the hypothesis is in favour of large-scale tourism development as part of the overall regional economic and business development.

The analysis of the data confirmed lower-level hypothesis 1 (h1) which states that the local residents are familiar with the active measures of the Government of Vojvodina for the economic development of tourism. If the Government of Vojvodina accepts the strategic goal in the development of tourism, this will emphasize specialization instead of standardization and diversification instead of uniformity, so other ancillary businesses will have to adapt to it. This will bring up new projects and new opportunities. Reaching the right position in the tourism market in Europe and elsewhere is very difficult especially in the time of political and economic instability in the country. By the number of 
beds, number of visits and overnight stays, Vojvodina is still at the level of the 1960s or 1970s. It is often said that the right way to achieve success in tourism and getting closer to Europe is to review the status of the past, learn from experience, create positive elements and eliminate limiting factors.

Lower-level hypothesis $2(\mathrm{~h} 2)$ also confirms that the local population is experiencing as positive all the active measures of the Government of Vojvodina in their efforts to reduce the unemployment rate. The participants replied that the positive aspects are new jobs, selfemployment, the revival of the villages and area development. Employment is seen in the broader context of the new jobs, either in the private or public sector. The fact is that the need for complex of tourist services encourages the development of a number of other activities from the industry and outside it, and therefore indirect effects of tourism on increase of the number of active employees in the activities involved in the formation of the tourist supply should be taken into account. Many of these activities would not have the existing facilities and manpower without support from tourism. Employment is seen in the broader context of the new jobs, either in the private or public sector. The fact is that the need for complex of tourist services encourages the development of a number of other activities from the industry and outside it, and therefore indirect effects of tourism on increase of the number of active employees in the activities involved in the formation of the tourist supply should be taken into account. Many of these activities would not have the existing facilities and manpower without support from tourism.

Local residents are not familiar with the project: "Functional connection between the excursion tourism and cycling tourism in the Fruška Gora Mountain"; and that was the rejection of the lower-level hypothesis $3(\mathrm{~h} 3)$. This is because they lack knowledge of tourism and associated skills, and because of the priority placed upon economic growth by the policymakers, with little concern for equity.

Lower-level hypothesis $4(\mathrm{~h} 4)$ also confirms that the local residents positively evaluated the implementation of projects related to tourism on the mountain. These projects are managed by the relevant national ministry which has been responsible for the preparation of the national strategy for tourism, training and investment programs, projects and infrastructure development and other activities that can improve investment conditions in Serbia. In addition to the fact that they connect people, cross-border cooperation between EU member states and their neighbouring partner countries represents investment in building human capacity and institutions that jointly develop and implement the projects dealing with their common economic and social challenges.

The term "'policy" is in conflict with the purely economic objectives (Hall, 1994; Bhat, Tang, 2001), on the one hand, and general social status or the status of individual states in the creation of global processes in the world, on the other hand. Connected into one unit like tourism economic policy it must monitor tourism so as not to disturb the movements between tourism supply and tourism demand. These trends must be considered unique as there are tourists all over the world with the same or similar motifs, but the environment in which they are located and accomplish their goals of travel is different. Therefore, tourism 
policies of all countries come from the state of socio-economic system and economic interrelationships of various economic activities.

The process of economic development imposes the micro and macro aspects of economic policy. At the macro level, globalization of tourism requires the latest enterprise organization, direct providers of tourist services and as well as complementary ones that perform processing on the tourist market and distribute tourism trends. In this regard, the management gets the integral position of connecting all the executive functions of successful business in tourism enterprises, while the part of management that determines the development strategy of the company is closely related and directly affected by macroeconomic policy in tourism. It means that the states through their individual instruments perform integration of individual global goals into a unique objective i.e. one that is accepted by the international community.

Positive economic effects of tourism development are reflected in many ways (de Oliveira, 2003). The money spent by foreign tourists in the country has a multiple effect, thus generating multiple effects on national income and employment. Spending by foreign tourists causes the initial impetus that begins the multiplier sequence. This consumption is topped with income from foreign countries, which passes through a series of activities and branches, as long as it is not transferred abroad, on imports of goods and services, or it changes in domestic savings. Of all the direct effects, the most important is the balance of payments and foreign exchange impact of tourism economic theory, or so-called phenomenon of "invisible exports" - created by providing services to foreign tourists. It is the realization under the very favourable circumstances, where the provision of travel services provides better prices for agricultural products, rather than through traditional exports.

The main reason lies in the nature of tourism demand for food and drink in a tourist destination. Besides the fact that agricultural products are sold to foreign tourists at prices that are significantly higher than exports, it is important that the realization is in the country of production, so there is elimination of transportation costs and protectionist barriers to foreign markets. Various types of import quotas, high standards of health and environmental suitability, rigorous quality control are thus eliminated through the implementation of agricultural products through tourism services. Therefore, foreign currency inflow from such exports is the largest. It is relatively easy access to such export, with the possibility of employment of local residents, in the tourism industry, and the accompanying activities (Cheong, Miller, 2000).

Among all the activities the agriculture occupies an important place (Pešić, 1996). As a potentially new tourist country, which seeks its place in the tourist market, the Republic of Serbia has a good opportunity to direct the development of tourism in the right direction, for several reasons: it can choose good and bad experiences of other countries; it can create tourism products and its market position in accordance with the latest trends; it cannot act quickly due to the inherited infrastructure and organization in tourism; it may use a critical mass of knowledge and internal capacity as the advantage of quick entry into the international tourism competition. 
The Republic of Serbia has to gain the trust of the international tourism business. In this regard, and in order to carry out its tourism industry in the world market, The Republic of Serbia has to establish a professional institutional infrastructure in the form of special centralized institutions (agencies). It would have to play a key responsibility for the development and growth of selected Serbian tourism products.

\section{References}

1. Andereck, K. L., Nyaupane, G. P. (2011): Exploring the nature of tourism and quality of life perceptions among residents, Journal of Travel Research, no. 50, pp. 248-260.

2. Bramwell, B. (2011): Governance, the state and sustainable tourism: a political economy approach, Journal of Sustainable Tourism, vol. 19(4/5), pp. 459-477.

3. Besculides, A., Lee, M. E., McCormick, P. J. (2002): Residents' perceptions of the cultural benefits of tourism, Annals of Tourism Research, vol. 29(2), pp. 303-319.

4. Bhatt, N., Tang, S. Y. (2001): Delivering microfinance in developing countries: Controversies and policy perspectives, Policy Studies Journal, vol. 29(2), pp. 319-333.

5. Bevir, M. (2009): Key concepts in governance, London: Sage.

6. Cheong, S., Miller, M. L. (2000): Power and tourism: A Foucauldian observation, Annals of Tourism Research, vol. 27(2), pp. 371-390.

7. de Oliveira, J. A. P. (2003): Government responses to tourism development: Three Brazilian case studies, Tourism Management, no. 24, pp. 97-110.

8. Elliott, J. (1997): Tourism: Politics and public sector management, New York: Routledge.

9. Hall, C. M. (1994): Tourism and politics: Policy, power and place, Chichester, England: John Wiley \& Sons.

10.Hall, C. M. (2005): The role of government in the management of tourism: the public sector and tourism policies, In: L. Pender, R. Sharpley (Eds.) The management of tourism (pp. 217-230), Thousand Oaks, CA: Sage Publications.

11. Jackson, M. S., Inbarakan, R. J. (2006): Evaluating residents'attitudes and intentions to act toward tourism development in Regional Victoria, Australia, International Journal of Tourism Research, no. 8, pp. 355-366.

12. Kim, S. S., Timothy, D. J., Han, H. C. (2007): Tourism and political ideologies: a case of tourism in North Korea, Tourism Management, vol. 28(4), pp. 1031-1043.

13. Luhiste, K. (2006): Explaining trust in political institutions: some illustrations from the Baltic States, Communist and Post-communist Studies, vol. 39, pp. 475-496.

14. Latkova, P., Vogt, C. A. (2012): Residents' attitudes toward existing and future tourism development in rural communities, Journal of Travel Research, vol. 51, pp. 50-67.

15.Liu, J., Var, T. (1986): Residential attitudes toward tourism impact in Hawaii, Annals of Tourism Research, vol. 13, pp. 193-214.

16. Mishler, W., Rose, R. (2001): What the origins of political trust? Testing institutional 
and cultural theories in post-communist societies, Comparative Political Studies, no. 34, pp. 30-62.

17. Mishler, W., Rose, R. (2005): What are the political consequences of trust? A test of cultural and institutional theories in Russia, Comparative Political Studies, vol. 38(9), pp. 1050-1078.

18. Nyaupane, G. P., Timothy, D. J. (2010): Power, regionalism and tourism policy in Bhutan, Annals of Tourism Research, vol. 37(4), pp. 969-988.

19. Nunkoo, R., Smith, S. L. J. (2013): Political economy of tourism: Trust in government actors, political support, and their determinants, Tourism management, vol. 36, pp. 120 132.

20. Nunkoo, R., Gursoy, D. (2012): Residents'support for tourism: an Identity perspective, Annals of Tourism Research, vol. 39(1), pp. 243-268.

21. Nunkoo, R., Ramkissoon, H. (2009): Applying the means-end chain theory and the laddering technique to the study of host attitudes to tourism, Journal of Sustainable Tourism, vol. 17(3), pp. 337-355.

22. Nunkoo, R., Ramkissoon, H. (2011): Developing a community support model for tourism, Annals of Tourism Research, vol. 38(3), pp. 964-988.

23. Nunkoo, R., Ramkissoon, H. (2012): Power, trust, social exchange and community support, Annals of Tourism Research, vol. 39(3), pp. 997-1023.

24. Nunkoo, R., Ramkissoon, H., Gursoy, D. (2012): Public trust in tourism institutions, Annals of Tourism Research, vol. 39(3), pp. 1538-1564.

25. Purcell, M., Nevins, J. (2005): Pushing the boundary: state restructuring, state theory, and the case of US: Mexico border enforcement in the 1990s, Political Geography, vol. 24(2), pp. 211-235.

26. Pešić, R. (1996): Turizam-vrhunski vid realizacije poljoprivrednih proizvoda, Zbornik radova "Poljoprivreda i turizam Jugoslavije", Savez poljoprivrednih inženjera i tehničara Jugoslavije, Beograd.

27. Ruhanen, L. (2013): Local government: facilitator or inhibitor of sustainable tourism development, Journal of Sustainable Tourism, vol. 21(1), pp. 80-98.

28. Serbia tourism development strategy (2005), Retrieved January $22^{\text {nd }}, 2013$, from Novi Sad University, Department of Geography, Tourism and Hotel management, available at: www.dgt.uns.ac.rs/ download /ektur04v.pdf

29. Vujko, A. (2011): Fruška gora i Vršačke planine - sadašnje i buduće destinacije sportsko-rekreativnog turizma, doktorska disertacija, PMF, Departman za geografiju, turizam i hotelijerstvo, Novi Sad.

30. Wang, Z. (2005): Before the emergence of critical citizens: economic development and political trust in China, International Review of Sociology, vol. 15(1), pp. 155-171.

31. Wang, Y., Bramwell, B. (2012): Heritage protection and tourism development priorities in Hangzhou, China: a political economy and governance perspective, Tourism 
Management, vol. 33, pp. 988-998.

32. Wong, T. K., Wan, P., Hsiao, H. M. (2011): The bases of political trust in six Asian societies: institutional and cultural explanations compared, International Political Science Review, vol. 32(3), pp. 263-281.

\title{
UTICAJ VLADINE POLITIKE NA EKONOMSKI RAZVOJ TURIZMA
}

\author{
Aleksandra Vujko ${ }^{3}$, Tamara Gajic ${ }^{4}$ \\ Rezime
}

Tajkuni i političari su glavni , igrači“ u oblasti turizma u većini delova sveta, $i$ oni često koriste turizam kao „sredstvo“ za sticanje ekonomske i političke moći, te stvaranje pozitivne, iako propaganizovane, slike svoje zemlje. Rad se bazira na pozitivnom primeru odobrenog projekta od strane Vlade Vojvodine i Sekretarijata za nauku i tehnološki razvoj. Glavni cilj ovog rada je pokazati da su lokalni stanovnici upoznati s projektom i koliko oni znaju o projektu, kao i šta je njihovo mišljenje o uticaju koji ovaj projekt $i$ drugi slični projekti imaju na posmatrani prostor (Fruška gora - Srbija). Zaključakje da postoji direktan pozitivan odnos između percepcije stanovništva o prednostima turizma i političke podrške države. Istraživanje je sprovedeno metodom slučajnog uzorka kod stanovništva sedam lokalnih naselja (uzorak od 249 ispitanika). Podaci su obrađeni SPSS programom (verzija 17.0). Da bi se odredila učestalost određenih odstupanja korišten je hi-kvadrat test.

Ključne reči: turizam, vladina politika, ekonomski razvoj, lokalno stanovništvo, Vojvodina.

3 Dr Aleksandra Vujko, Visoka poslovna škola strukovnih studija, Vladimira Perića Valtera, 21000 Novi Sad, Srbija, Telefon: +381 6491426 45, E-mail: aleksandravujko@yahoo.com

4 Dr Tamara Gajić, Visoka poslovna škola strukovnih studija, Vladimira Perića Valtera 4, 21000 Novi Sad, Srbija, Telefon: +381 63565 544, E-mail: gajic_tamara@yahoo.com 